\title{
Biology teachers' conceptions of Humankind Origin across secular and religious countries: an international comparison
}

\author{
Heslley Machado Silva ${ }^{*} \mathbb{0}$, Alandeon W. Oliveira², Gabriela Varela Belloso ${ }^{3}$, Martín Andrés Díaz ${ }^{4}$ \\ and Graça S. Carvalho ${ }^{5}$
}

\begin{abstract}
Striving toward a better understanding of how the global spread of creationist ideology may impact biology teachers and teaching worldwide, this study comparatively examines how biology teachers from three Latin American countries (Argentina, Brazil, and Uruguay) conceive the origin of humankind. It is reported that teachers from Uruguay (the most secular country) and Argentina (a country with intermediate religiosity) more frequently associated humankind origin with scientific terms Evolution, Natural selection, and Australopithecus. In contrast, Brazilian teachers stood out as those most frequently associating humankind's origin to the religious term "God" alongside scientific terms. This study underscores the importance of the interplay of social factors (societal religiosity) and psychological factors (e.g., personal commitment) when considering the impact of teacher exposure to creationist ideology. It also highlights the need for biology teachers (particularly those in more religious countries) to undergo professional development.
\end{abstract}

Keywords: Humankind origin, Evolution, Creationism, Biology teachers

Initially limited to the US, the so-called Evolution Wars (public controversy about the exclusive teaching of Darwin's theory of evolution in school science) have reached many other countries across all continents. Headlines like "Creationism invades Europe" and "Evolution abroad: Creationism evolves in science classrooms around the Globe" sound the alarm on a seemingly global spread of the creationist movement, raising concerns about the potential growth of anti-evolution attitudes within public education systems worldwide (Blancke and Kjærgaard 2016; Harmon 2011; Miller et al. 2006).

Closely aligned with this international trend, Latin America, particularly Brazil, has recently witnessed increasing debate and controversy about religion, evolution, and public education (Cornish-Bowden and

\footnotetext{
*Correspondence: heslley@uniformg.edu.br

${ }^{1}$ University Center of Formiga-MG, Formiga, Brazil

Full list of author information is available at the end of the article
}

Cardenas 2007; Oliveira and Cook 2019; Salzano 2005). Initiatives to include creationism in school science have taken place in several Latin American countries (Sepulveda 2004; Souza 2009). Moreover, support for the teaching of creationism by high profile politicians (Silva and Prado 2010) and controversial legal rulings such as the Brazilian Supreme Court's recent approval of confessional religious teaching have sparked heated debate in the media and in political spheres about what should or should not be happening in public schools.

Meanwhile, American creationist groups like the Discovery Institute have published articles portraying Brazilian creationism as "flourishing" and "shining" (Wells 2017), and celebrating the collaborative launching of a research centre for creationist science in a leading university in Brazil (Klinghoffer 2017). There has been a rapid international rise in creationist influence, pointing out to a need to better understand the interplay of larger

c) The Author(s) 2021. This article is licensed under a Creative Commons Attribution 4.0 International License, which permits use, sharing, adaptation, distribution and reproduction in any medium or format, as long as you give appropriate credit to the original author(s) and the source, provide a link to the Creative Commons licence, and indicate if changes were made. The images or other third party material in this article are included in the article's Creative Commons licence, unless indicated otherwise in a credit line to the material. If material is not included in the article's Creative Commons licence and your intended use is not permitted by statutory regulation or exceeds the permitted use, you will need to obtain permission directly from the copyright holder. To view a copy of this licence, visit http://creativeco mmons.org/licenses/by/4.0/. The Creative Commons Public Domain Dedication waiver (http://creativecommons.org/publicdomain/ zero/1.0/) applies to the data made available in this article, unless otherwise stated in a credit line to the data. 
forces such as national religiosity and personal factors (e.g., commitment to science and/or religion), in a globalized era that allows for rapid worldwide travel of competing ideologies.

Studies on the acceptance of evolutionary theory and its teaching in Uruguay are scarce. Perhaps due to the country's secularism tradition, this topic does not figure prominently on the country's educational agenda. Humankind origin has been taught in Uruguayan schools since the nineteenth century, but with a more positivist bias and less from a religious perspective (Glick 2001). The few previous studies on Uruguayan teachers and the teaching of evolution confirm that the religious question does not pervade the Darwinian theory teaching (Silva et al. 2017, 2019).

On the other hand, in Argentina, several authors have investigated the topic since the nineteenth century (Levine and Novoa 2012). In this literature, the question of acceptance of evolution is addressed, with attention specifically paid to factors that can hinder its learning, obstacles such as common-sense teleology and linear causal reasoning (Galli and Meinard 2015). Moreover, the interface between religion and science, its teaching, and the possibility of conflict is highlighted in this research, highlight that the issue is historically complex in the country (De Ásua 2019).

Having the above global context in mind, we set out to compare how biology teachers from three Latin American countries (Argentina, Brazil, and Uruguay) conceive of the origin of humankind, we seek to understand better how a societal factor (national religiosity) interacts with personal commitment (to religion and/or science) under increasing pressure from the globalized forces of creationism. Ultimately, we expect to contribute to illuminating these multiple forces' interplay in shaping biology teachers' views in national contexts characterized by varying degrees of religiosity. We also recognize that other factors may occur in each country that may influence the conceptualization of teachers, such as cultural, economic, initial and continuing education, among others.

\section{International comparisons}

Rejection/acceptance of evolutionary theory has been shown to vary considerably from country to country depending on the relative degree of national religiosity. In a comparative study involving six countries (France, Germany, Greece, Italy, Turkey, and USA), MacDowell (2011) asked participants: "Did human beings, as we know them today, develop from earlier species of animals?" Respondents from the USA and Turkey tended to reply negatively, whereas those of European countries (France, Germany, Greece, and Italy) mostly replied positively to the questions. These divergent results suggest that the degree of national religiosity may influence citizens' views of evolution. In both the markedly Christian country of the USA and the markedly Muslim country of Turkey, support for creationism was found to be strong and widespread.

In contrast, in those countries with a secular tradition, especially France and Germany (but also to a lower degree in Italy and Greece), most of the population viewed the origin of humankind in terms of biological evolution. Similar trends have been consistently reported by many other comparative studies of different countries, including Chile and the Galapagos Islands (Marin and D'Elia 2016; Oliveira et al. 2019). This literature provides evidence that religiosity can influence general acceptance or rejection of evolutionary theory among the population at a national level. Economic status as a developed or developing country seems relatively less influential.

Consistent with the above trend, a national survey recently revealed that, though evolution is accepted by more than half of the population (54\%), the overwhelming majority of Brazilians (89\%) believe that creationism should be taught in schools and that it should replace the theory of evolution in the school curriculum (75\%) (Brum et al. 2005). These high levels of acceptance of creationism and rejection of evolution are somewhat unsurprising, given Brazil's high religiosity level compared to other countries in South America (Pew Research Center 2018).

An important question that should be considered is the recent change in the religious scenario of Latin America. Particularly noteworthy is the recent growth in the number of evangelicals associated with the decline in the number of Catholics in Brazil (Silva and Mortimer 2014), the election of an Argentinean pope which reverberated across the continent (Wolff 2014), and the slight increase in the number of atheists and agnostics in the young population (Novaes 2004). All these dynamic phenomena can influence Latin American teachers' views of controversial issues like humankind origin. This rapidly changing scenario raises the question addressed in this study, namely, "how exactly does religion in its many forms and levels of manifestation (national, personal, among others) influence biology teachers' conceptions about the human origin in Latin America?".

Finally, it is necessary to dimension and analyse how teachers conceive the humankind origin through scientific bias in societies marked by religiosity (Silva and Mortimer 2019). Despite countless evidence of the evolutionary process that led to human origin, this was and still is one of the most rejected Darwinian evolutionary theory's theme. Therefore, teachers must be prepared to teach this topic and avoid misconceptions among students and even teachers (Bravo and Cofré 2016). The perception of common origin (man like any other animal) 
often clashes with the anthropocentric vision of nature (humans as superior beings distinct from other animals). Hence, it is imperative to capture how teachers conceive of humankind origin, and analytically consider how their conceptions can seep into the classroom and reach students (Pobiner et al. 2018).

\section{Other influential factors}

Despite its influential nature, care should be taken not to assume a direct causality between national religiosity/ secularity simply (how religious or secular a country is) and teachers' mental constructs (whether they hold creationist or evolutionary views of the origin of humankind). Such an assumption would be problematic because it would presume the existence of a deterministic relationship between society and cognition. Rather than being simply determined by nationality, how one conceives of humankind's origin is the result of a multitude of factors, including personal values, knowledge, amount of education, type of profession, years of experience, religious affiliation, cultural background, to name a few. Clément and Quessada (2013a) showed that the higher number of years of university-level training the less prominent creationist conceptions are among teachers. However, there is also evidence that even students of biology and medicine can have difficulty accepting evolution (Downie and Barron 2000). These conflicting findings highlight the need to consider multiple influential factors (education, personal values, among others) when contemplating the roots of teachers' views. Any single factor in particular does not determine teachers' evolutionary views.

In addition to the factors mentioned above, careful consideration must also be given to the role of scientific knowledge and professional membership to science. It would seem reasonable to expect individuals who are knowledgeable about science and who have sciencerelated professions to fully subscribe to evolutionary views (i.e., creationists simply lack the necessary knowledge). However, research shows that this is not necessarily the case. In a comparative study of life scientists in the UK and Brazil, Falcão (2008) found that Brazilian scientists believed in the supernatural more strongly than British scientists despite their common advanced scientific training. Brazilian scientists shoed to retain a firm attachment to a belief in God regardless of their university training level, e.g., scientific knowledge did not necessarily lead them to give up their belief in God.

Similarly, Souza et al. (2009) has shown that many biological sciences students hold on to creationist views despite their many years of scientific training. Silva (2015) has shown that many biology teachers in Latin America continue to focus on divinity when considering evolution and life origin. Jalil (2009) also points out that many teachers concurrently use scientific and religious explanations. They build conciliatory arguments on what they learned from the religion they practice. Some take a stance called "neo-creationism," which views intervention of God in the origin of life and at different stages of the evolutionary process, hence transforming evolution theory into a kind of natural law. For these teachers, the evolution theory is not in itself incompatible with Christian faith (Sanz 2013).

In sum, the above literature shows that the relationship between scientific training/knowledge and religious belief is far from simple and straightforward. Being a knowledgeable and experienced member of the science profession does not necessarily guarantee one's full embracement of evolutionary views or dismissal of creationist ones.

\section{Methodology \\ Participants}

Our participants included 50 biology teachers from Argentina, 62 biology teachers from Brazil, and 57 biology teachers from Uruguay. The choice of these countries was due to their varying degrees of religiosity as well as the distinct State-Church relationships prevalent in each country. As recent surveys have shown (Pew Research Center 2018), there is a wide variation in religiosity in Latin America, with religion being more relevant to people in Brazil (72\% consider it important) and less relevant as one moves south towards Argentina (40-59\% in Argentina). Religiousness reaches its lowest in Uruguay where the share of those who say religion is important is only $29 \%$. Having the highest level of religiosity, Brazil can be considered a "false secular" country. Although officially secular, religiosity is noticeably high, and religion strongly influences various spheres of Brazilian society (Cunha 2009). In contrast, despite its relatively lower religiosity, Argentina is officially a Catholic country (i.e., a non-secular nation), as indicated in its constitution (Esquivel 2003). Finally, Uruguay stands out in South America for its vigorously consolidated secularism (Da Silva and Mendonça 2008). By comparing how biology teachers across these countries conceive humankind's origin, we sought to better understand how national religiosity interacts with personal commitment (to religion and/or science) in giving rise to creationist/ evolutionist views. The question of religiousness was previously used as a parameter to analyse teachers' conceptions, using the same questionnaire, resulting in analyses that were published (Clément 2014). 


\section{Data collection}

The main instrument of data collection used in this study was the BIOHEAD-CITIZEN questionnaire (Carvalho and Clément 2007). Part of a broader European research project called "Biology, Health and Environmental Education for better Citizenship," the questionnaire was developed by an international group in Portuguese, English, Spanish and French. It was validated in all these languages and implemented in 19 countries in Europe, the Middle East and Africa. The project's starting point was to understand how teachers of diverse social contexts perceived controversial topics such as the humankind origin and evolution, sex education, health, and environment. In the present work, we focus specifically on question A62: "In the list below, tick the THREE expressions that you think are the most strongly associated with the origins of humankind. Respondents had to select three alternatives out of the list of six possible answers. Half of the alternatives were linked to the religious field (Adam and Eve, Creation, and God) and the other half to the scientific field (Australopithecus, Evolution, Natural Selection). This questionnaire was previously used to compare teachers' conceptions in various countries and continents. It has been applied to thousands of individuals and been reported on in various publications, showing clear evidence of its relevance as a research tool (Clément 2015; Clément and Quessada 2013). The BIOHEADCITIZEN questionnaire was previously used to analyse the religion influence on teachers' acceptance of humankind origin and evolution in South Africa. It revealed the importance of this religions factor for teachers' conception of humankind origin (Clément and Quessada 2009).

The first expression "Adam and Eve" may appear far from the reality of those who believe in evolution, but the inclusion of these mythical figures in the question is justified by their strong roots in Western Christian religious culture and history (Almond 2008; Livingstone 2008; Enns 2012). The term "Creation" can be perceived antagonistic to the evolutionary phenomenon, perceived by those followers of the most radical forms of creationism, such as the creationism of Young-Earth. However, on the other hand, theistic evolutionists achieve some form of compatibility between science and religion, considering creation as compatible with evolutionary theory. Therefore, there is graduation of this capacity for acceptance of Darwinian theory among believers (Devine 1996; Scott 1999). In more religious spaces, the conception of creation as contrary to evolution is probably more frequent. The figure of "God" is usually associated also with

\footnotetext{
${ }^{1}$ It seems to me absurd to doubt that a man may be an ardent Theist $\mathcal{E}$ an evolutionist. Darwin Correspondence Project, "Letter no. 12041," accessed on 22 September 2018, http://www.darwinproject.ac.uk/DCP-LETT-12041.
}

antagonism to evolution, but again this is not necessary, Darwin himself did not have this perception. ${ }^{1}$ Today renowned scientists have achieved this compatibility and spread this possibility (Collins 2006; Ayala 2007), and those followers of the intelligent design movement, a form of creationism, supposedly would have found a way to do so, but for that, they deny the main evolutionary assumptions scientifically proven (Pennock 2003).

"Natural selection" is one of the most important concepts when articulating evolutionary explanations (Nehm and Reilly 2007). Indeed, the important role of natural selection in evolutionary processes is underscored by an extensive body of scientific evidence, ranging from genetics to fossil records (Stringer and Andrews 1988). Therefore, biology teachers must associate the origin of humankind with natural selection. This association importance for the teaching of evolution has been pointed out in several studies highlighting the need to find ways for it to be assimilated by students (Lucero et al. 2017; Clarke-Midura et al. 2018). Furthermore, the term "Australopithecus" refers to the ancient line of the genus Homo as described in several works such as Lovejoy (1981) and Leakey (1995). Therefore, it would be expected for biology teachers to consider this ancestral genus as a key term in any account of humankind's origin. Teaching this topic can be difficult due to misconceptions such as the perception that man originated from the monkey and conflicts with creationist conceptions such as intelligent design (Tibayerenc and Ayala 2020; Silva and Mortimer 2020). The term "Evolution" can be perceived as a synthesis of evolutionary theory, also often perceived as an atheistic approach (Dawkins 2016; McGrath and McGrath 2011), therefore rejected by religious, despite the need for this antagonism. It is important to conceive that this concept is expected to be widely accepted by professors of Biology, in any country, because it is supported by a large set of evidence (Coyne 2010).

Our questionnaire data were supplemented by interviews. More specifically, interviews were conducted with ten teachers in each of the three countries. Guided by a semi-structured interview protocol, teachers were prompted to elaborate on their survey responses. Three axes of discussion guided the interviews: (i) What are the obstacles to teaching biological evolution in the country (if any)? (ii) What usual conflicts occur when teaching the subject of Darwinian evolution? (iii) How does biological evolution feature in your country's school curriculum?

Due to the accessibility and availability of time for the interviews, teachers who had answered the questionnaire were invited to be interviewed. The interviews allowed the teachers to speak freely about the suggested topics and lasted between 20 and $40 \mathrm{~min}$. 
Table 1 Distribution of religions in the general populations of Argentina, Brazil and Uruguay (Oro 2008)

\begin{tabular}{llccc}
\hline Countries & $\begin{array}{l}\text { Catholics } \\
\text { (\%) }\end{array}$ & $\begin{array}{l}\text { Evangelicals } \\
\text { (\%) }\end{array}$ & Others (\%) & $\begin{array}{l}\text { Non- } \\
\text { religious (\%) }\end{array}$ \\
\hline Argentina & 88.0 & 8.0 & 2.0 & 2.0 \\
Brazil & 73.6 & 15.4 & 3.6 & 7.4 \\
Uruguay & 52.0 & 2.0 & 11.0 & 35.0 \\
\hline
\end{tabular}

\section{Data analysis}

Our analyses considered the creationist/evolutionist views expressed by teachers, their religious affiliation (as declared in the questionnaire and interviews), as well as the national conditions (relative level of religiosity) in their home country. In the quantitative phase, statistical analysis of data was carried out with the software STATISTICA 5.5. At first, using the Kruskal-Wallis test, it was found that the degree of agreement differed significantly among the three countries. Subsequently, the Mann-Whitney test was used to compare pairs of countries. This way it is intended that the two tests may have been complementary in the analysis of quantitative data. The size of our sample was found to be satisfactory, being larger than those of other studies that have used the BIOHEAD-CITIZEN questionnaire (Khzami et al. 2008; Munoz et al. 2009; Berger et al. 2011; Quessada and Clément 2011; Caldeira et al. 2012).

Additionally, we conducted a qualitative analysis of teachers' interview responses through the technique of Collective Discourse (Lefevre and Lefevre 2006), which seeks to find a pattern in the discourses of a given category. This allowed for triangulation between interview answers and questionnaire responses. The KVP model guided this qualitative analysis, an analytical framework previously used as part of the BIOHEAD-CITIZEN project, as already used in other publications that have made comparative analyses using the same questionnaire (Clément 2006, 2016). In this model, personal views of evolution are seen as a result of the interaction between " $K$ " (one's scientific knowledge), "V" (one's system of values, including those of a religious nature), and " $\mathrm{P}$ " (referring to social practices such as teaching). The analysis using this model sought to qualitatively uncover how each country's socio-cultural context influences teachers' relationship with science, given their personal values and professional practices.

As part of our qualitative analysis, we also considered teachers' views of the relationship between science and religion. To do so, we used the four categories proposed initially by Barbour (1990) and later elaborated upon by Coutinho and Silva (2013), namely Conflict, Independence, Dialogue, and Integration. In the Conflict category,

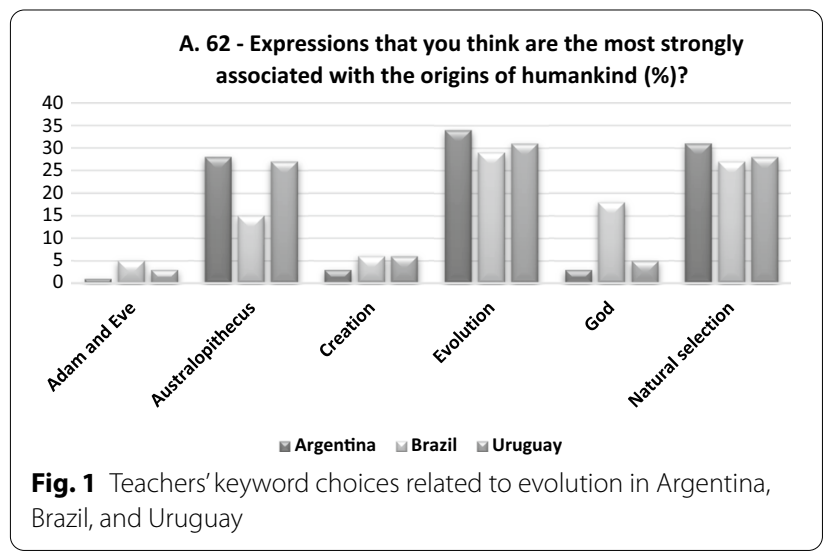

science and religion are viewed as non-reconcilable and mutually exclusive. Science and religion are separate, with one side considering itself to be the owner of the truth in detriment to the other. Likewise, in the Independence category, science and religion are seen as distinct traditions and forms of knowledge, with very little to say about each other. Given their incompatible distinction, science and religion should not overlap or interfere with each other. The third category, Dialogue, admits some form of interaction between science and religion in a less rigid way. Despite being independent of religion, science may resort to its support and establish a dialogue with religion in the quest for answers. Lastly, in the Integration category, the borders between science and religion are fuzzy, with the holder often invoking "natural theology" to explain God's existence.

\section{Results}

The distribution of religious affiliation among our participants are as follows. Most of the participants were Catholic: 58\% in Argentina, 55\% in Brazil and 49\% in Uruguay. Catholics were followed by Evangelicals, who in Brazil made up $11 \%$ of our sample-higher when compared to the other two countries, Argentina (5\%) and Uruguay (4\%). Moreover, our Brazilian sample had a high number of Spiritualists (24\%), a denomination that no teacher declared in the other two countries. Finally, a relatively high number of agnostic/atheist were found among the teachers from Argentina and Uruguay (26\% and 37\%, respectively) compared with the low number for Brazilians teachers (7\%). Despite some small differences, our sample of biology teachers had a reasonable degree of similarity in religious configuration with the three countries' general population (see Table 1). 


\section{Survey responses}

Overall, when prompted to select the terms most strongly associated with the origins of humankind, respondents in all three countries most frequently chose "Evolution", "Natural selection" and "Australopithecus" (percentages of answers provided by biology teachers from Argentina, Brazil and Uruguay can be found in Fig. 1). In comparison, the percentages of participating biology teachers who chose any of the religious alternatives (Adam and Eve; Creation; God) were very low (below 6\%). The only exception was the term "God," which was selected by a larger proportion of Brazilian participants (18\%) compared to Argentinian participants (3\%) and Uruguayan participants (5\%). Despite their years of science training and scientific knowledge, these biology teachers still considered this biblical figure relevant to human origin.

In our analyses, the results related to the themes were highlighted "Adam and Eve", "Australopithecus" and "God", because they presented themselves in a more differentiated way among the countries, besides being significant regarding religious and scientific issues. The themes "Creation", "Evolution" and "Natural selection", presented little variation among the countries, with little relevance in the comparative analysis.

Statistical analysis by the Kruskal Wallis test showed no significant difference among the three countries $(\mathrm{M}=2.71 \mathrm{p}=0.25)$, indicating that participating biology teachers were mainly evolutionists because the answers concerning the themes considered scientific from the evolutionary point of view were relevant in all three countries: Australopithecus, Evolution and Natural Selection. The statistical differences about religion topics were not significant either, but when we isolated some of these topics, the differences were revealing. Thus, there was a noticeable variation in the proportion of participating teachers who selected the term "Australopithecus": $28 \%$ in Argentina, 27\% in Uruguay and only 15\% in Brazil. Likewise, the percentages of participating teachers who selected "natural selection" was slightly lower for Brazil.

In sum, our quantitative results revealed that participating biology teachers from all three countries tended to favour scientific knowledge $(\mathrm{K})$ by selecting more frequently "Evolution", "Natural selection" and "Australopithecus". However, Brazilian participants turned to religious values (V) more often when expressing their personal views about humankind's origin. Such a finding is consistent with relatively high religiosity of Brazil compared to its South American counterparts.

\section{Interview responses}

The above differences between participant biology teachers from Brazil and their Argentinean and Uruguayan counterparts were evident during the interviews. When discussing human's origin, participating teachers from Brazil often produced answers that contained a mixture of scientific and religious ideas (unlike teachers from the other countries).

While elaborating on his survey response, about the obstacles to teaching evolution, one Brazilian teacher commented that "Religion, there is no way... I have tried everything that is, but honestly, I am a professional, I have doubts about these issues... Regardless, when you look at the stories, there were other animals before, before Adam and Eve, and the other people, it's a lot, I think, I think it's very complicated... it's the trickiest part I think so within the sciences is evolution." Such comments suggest a complicated attempt to accommodate knowledge about evolution in the face of his religious beliefs,

Another Brazilian biology teacher commented when he answered about the conflicts occurring when teaching the subject of Darwinian evolution: "they also say some believe that man came from a monkey, so I mean, I ask them if we came from the monkey why there is not a monkey turning into people..." This same teacher added "Who directed this evolution? It was something superior; what superior thing is that? For us, we say it's God..." For this biology teacher, the figure of God is part of his elaboration of human origin. This teacher incorporated in his mixture of religion and science, two misconceptions that are explored by the detractors of evolutionary theory (Relethford 2017). The misconception that human beings came from the ape and not from a common ancestor and the idea claimed by the intelligent design movement that God participated in human origin (Luskin 2005). This kind of insertion and appropriation of knowledge has been underscored as potentially harmful to science education quality (Silva 2017).

Other responses from participating Brazilian teachers indicated alternative ways of conceptualising human evolution. One teacher stated that when he talked about internal conflicts over the teaching of evolution: "starting with the evolution of man, if you take the Bible, then you will fall into Adam and Eve, Cain and Abel... and then what?" This comment reveals a perceived conflict between scientific knowledge and religious beliefs. By placing religion and science in the same line of thought, the teacher eventually created a stalemate, making it difficult to reconcile the two perspectives. As can be seen, religion was an important part of this teacher's conception of humankind origin. His comments corroborate what was also revealed by the questionnaire, namely, that participating Brazilian teachers strongly associated Adam and Eve to the origin of humankind.

An attempt to integrate scientific and religious knowledge was also evident in another Brazilian teacher's answer who stated that "these evolutions, these changes, 
came in forty days. The reading that many make of the Bible, it is very literal. So, it prevents this scientific knowledge from being well interpreted, right?" To this teacher, it seems that the perceived conflict would be resolved by integrating biblical precepts with biological evolution concepts. Another example of this integration process was captured when a teacher, a spiritualist, stated that he teaches the evolution of the human spirit when he explains the evolutionary theory.

The Argentinean and Uruguayan teachers did not view the teaching of evolution as problematic or challenging. The response of an interviewed Argentinean teacher illustrates this perception of the teaching of evolution in his country: "Well, yes, I am a teacher at the secondary level and a teaching assistant at the tertiary level and the truth is that there is no problem regarding the teaching of evolution. Not at least in terms of impediment or religious beliefs that exist in other countries, for example. We don't have any type of "contestation", or any kind of difficulty in teaching her about it." Another Argentinean teacher reinforced, in a more categorical way, this view of there not being any pedagogical obstacles: "No, in the province of Buenos Aires, whether in private or state schools, there is no problem from an ideological perspective, even I worked in Catholic schools, and they never made me approach the ideological issue of creationism."

The Uruguayan teachers expressed similar views. This was particularly clear in teacher comments like "No, no, they [students] accept the different theories, theories of the origin of life, and do not reject anything generally, spontaneous generation, I have not had problems. They don't tell me anything, they accept different criteria, they don't externalise much." Another Uruguayan teacher even theorised about why there were no significant obstacles to teaching biological evolution in that country: "I think that is due to the historical process in our country, the rapid separation of the church and the state, when it began to separate. Personally, I have always worked in the public sphere, there is no evolution instruction in a Christian school, but in the public sphere I have not encountered this problem."

In summary, the ten Brazilian teachers who participated in this study showed a greater tendency to adopt hybrid conceptions of humankind origin that mixed science and religion. Further, for these Brazilian teachers, religion constituted a way to compensate for a seemingly limited scientific knowledge. In addition, these same teachers considered religious conceptions of humankind as the greatest difficulty in the teaching evolution. In contrast, the ten (from each country) participating teachers from Argentina and Uruguay held stronger and more accurate conceptualisations of evolutionary processes and identified different reasons for their pedagogical difficulties when teaching evolution and human origin. These teachers showed that they could differentiate and separate their religious and scientific views, in agreement with Barbour's epistemological category of independence.

\section{Discussion}

\section{National religiosity}

Our results indicate that national religiosity is indeed a societal factor that should be considered when considering how biology teachers from a given country view evolution-related topics such as human origin. As reported above, participating teachers from Uruguay-the most secular country, notorious for its lay tradition and a large number of atheists and non-religious (Da Costa 2020) - more frequently associated the notion of human origin with scientific terms Evolution, Natural selection, and Australopithecus. Similar patterns were also found among participating teachers from Argentina (a country with intermediate religiosity/secularity). Finally, Brazilian teachers who participated in this study stood out as those most frequently associating humankind's origin to the religious term "God." Another characteristic of participating Brazilian teachers was that, differently from Argentine and Uruguayan participants, they considered that state and religion do not need to be separated. This is consistent with the findings of another study that also examined the interference of personal beliefs in Brazilian teachers' humankind conceptions (Silva et al. 2015).

Even after learning about the reconstruction of human phylogeny, showing its connection with Australopithecus (Wood 1992), many Brazilian biology teachers considered God more relevant to the human origins than the ancestral hominid. This finding is consistent with previous studies. Silva et al. (2014) have described how, in a Brazilian population sample, there was considerable opposition to Darwinian evolutionary theory's teaching in the absence of the figure of God, especially among those followers of evangelical religion. Silva et al. (2015) and Clément et al. (2009) have reported that it is possible for some Brazilians to believe in God and in biological evolution without any perceived contradiction. Sepúlveda (2003) has described how Brazilian students' religiosity majoring in biological sciences influenced their conceptions of evolution. Indeed, these studies show that many Brazilian teachers hold views of evolution combined/merged with non-scientific concepts. These recurrent allusions to God by Brazilian biology teachers support Edwards' (1999) argument that it is very complicated for a Christian with strong fundamental beliefs to fully embrace evolution (to the full exclusion of creationism) when explaining human origin. Likewise, Brazilian teachers in the present study were the ones who most 
often associated the origin of humankind to Adam and Eve in an apparent effort to incorporate ideas from the religious sphere with scientific content.

Although the role of "Australopithecus" in human evolution is scientifically clear, as evidenced by fossils that allow a phylogenetic construction of this process (Bramble and Lieberman 2004; Leakey 1995), the number of biology teachers who did not attribute importance to Australopithecus to the origin of the humankind was relatively high in Brazil as compared to the other countries. As emphasised by Fahrenwald (1999), this is a common problem among biology teachers whose limited scientific knowledge on this topic leads many to ignore it. This finding that participating Brazilian teachers' views of human origin were more religiously oriented than those of Argentines and Uruguayans was confirmed by another study that also used BIOHEAD-CITIZEN, which questioned whether the origin of humankind was a natural phenomenon. For a significant portion of Brazilian biology teachers in this other study, God's influence in this process was seen as certain, unlike their colleagues who, in the majority, do not consider this hypothesis (Silva et al. 2019). It is difficult to define that there may be some impact of these conceptions of Brazilian teachers in their classes about evolution, but it is clear that these teachers open more space for their beliefs than for their scientific knowledge in some analyses. Based on the KVP model, one can conclude that the practice $(\mathrm{P})$ of these teachers may be less linked to scientific knowledge (K) than to implicit values $(V)$, such as religion (Clèment 2006).

It is important to recognise limitations in our findings and in generalising them to a national level. One important limitation is our relatively small sample size. When considering the significance of the reported findings, one must exercise caution and assume the possibility of complications such as regional/local variations that might preclude simple and direct generalisation to the entire universe of teachers in each country. However, triangulation of multiple data sources (questionnaire and interviews) and noticeable consistency with previously reported findings in the pertinent literature gives confidence that possible validity threats were reduced to reasonable levels.

\section{Personal commitment to science and/or religion}

Latin American teachers of biology who participated in this study tended to favour scientific knowledge (K) by selecting more frequently "Evolution", "Natural selection" and "Australopithecus." However, despite their professional commitment to science and biology, many participating teachers' personal views were not completely devoid of religious values $(\mathrm{V})$ when expressing their personal views about humankind's origin. This was particularly the case for teacher-participants in national contexts characterised by high religiosity like Brazil. Participating biology teachers who worked in such religious contexts tended to resort to dialogue and integration, simultaneously associating humankind origins to religious and scientific terms. In contrast, teacherparticipants from more secular countries (Uruguay and Argentina), favoured independence, more consistently associating human origins to scientific terms and separating science from religion.

The above findings highlight the important role of national religiosity when considering the potential impact that worldwide travel of creationist ideologies may have on biology teachers. In countries dominated by secular forces, participating biology teachers seem to be able to separate their professional commitment to science from any personal commitment to religion more easily-these remain as independent facets or spheres of their lives. In contrast, participating biology teachers in religious countries seem to look for epistemic ways to remain simultaneously committed to both science and religion. Rather than separate and independent, the scientific and religious endeavours were treated as belonging to a single, epistemologically hybrid realm wherein divinity and biological phenomena co-existed in apparent harmony. In doing so, these biology teachers found a way to inhabit two distinct epistemological worlds at once, and thus maintain a degree of coherence between their personal and professional lives. As emphasised by recent scholarship and theoretical work (Agnew 2009), commitment (whether personal, professional, organizational, moral, structural, epistemological, etc.) is a key psychological factor that, together with external social forces (e.g., religiosity), can influence human cognition, motivation and affect. Such a finding is not completely surprising given Brazil's long history of religious syncretism-the blending of multiple religious traditions or belief systems. Since colonial times, syncretic elements have pervaded Brazilian culture for a long time (e.g., the Afro-Brazilian religions). Thus, it seems natural for Brazilians who are used to syncretism to blend religious and secular elements when faced with two competing ideologies such as creationism and evolution.

The above findings are consistent with the previous literature. Jalil (2009) has described how there are multiples way to interpret or explain humankind's origin in terms of the participation of a divine figure in evolution. Two recurring syncretic explanations are the following: (a) God's intervention occurred at the beginning, being followed by chance (random acts evolution); and, (b) Goddirected evolution to reach its highest creation, human. "God directs mutations, God infuses the spirit, God works through miracles." This syncretic way of thinking is like 
those expressed by respondents who viewed evolution and God as simultaneously important to humankind's origin.

Another factor that can help explain the religiousinfused views of human origin held by Brazilian biology teachers' in this study is their professional training quality. Recent studies point out severe difficulties in the teacher education of science and biology teachers in Brazil (Araujo et al. 2009; El-Hani and Sepulveda 2010; Gatti 2016; Villani and De Freitas 2002). Provision of scientifically and pedagogically stronger training to Brazilian biology teachers could help reduce the arrival of creationist ideology in the country.

With the 2018 election of government officials linked to conservative and negationist movements in Brazil, it is expected that evolution education will become more problematic in the near future. The president of the main Brazilian research funding agency (CAPES) as well as the head of the Brazilian Ministery of Education have a professional trajectory linked to the University that created an institute for research and dissemination of intelligent design, the former having already expressed interest in the insertion of creationism in basic education in Brazil (Silva 2020).

\section{Conclusion}

This research was conducted in the context of changing religiosity in Latin America. The rise of a new conservative political scenario (Wiarda 2019), especially in the already troubled Brazilian scenario (Machado et al. 2018), has aroused interest in the academic field (Somma et al. 2017; Morello et al. 2017). In addition, the three examined countries have seen relatively weak student performance in international comparative tests of science education, such as PISA (Villar and Zoido 2016). Such trends underscore the importance of better understanding education and educational processes in the region (Avendano et al. 2016), among them possible difficulties in the teaching and learning evolution. As such, our study fills an important gap in the science education literature.

The difficulties demonstrated by teachers in scientifically viewing the origin of humankind may be related to misunderstandings about the nature of science. Therefore, it is urgent to pay attention to biology teachers' views of science in their professional training. More informed understanding of the nature of science can provide biology teachers with a more solid epistemology foundation of grasping conceptual aspects of evolutionary theory and repel pseudo-scientific interpretations/ arguments (Nelson et al. 2019). Regarding this issue, some approaches are suggested for teacher training to improve the learning of biological evolution: first teaching the main aspects of the nature of science; integrating evolution into the teaching of biology as a whole; using active pedagogies of learning in this process of integration; using alternative assessments when dealing with this topic; and, providing a broader understanding of biology as a whole (Scharmann 2018).

Difficulties related to evolutionary theory also highlight the need for greater conceptual knowledge on the subject. As reported, participating teachers from Argentina and Uruguay demonstrated having greater contact with the subject in their training. In this regard, research shows that, in teacher training courses, a blunt presentation (initial and continuous) of evolution issues promoting the understanding of the scientific theory that works as an antidote to attenuates the influence of creationist considerations and its supposedly scientific version, such as intelligent design (Holt et al. 2018). In this way, religious precepts can be accommodated in the face of scientific knowledge, since conflict is unnecessary and counterproductive, and there is no need to abandon religious conceptions in order to understand and accept biological evolution, something already perceived by Charles Darwin himself in one of his last letters. ${ }^{2}$

In addition to considering epistemological difficulties associated with the teaching and learning of humankind origin, it must be recognised that national religiosity is an important factor when in better understanding how the global spread of creationist ideology may impact biology teachers and teaching worldwide. Close attention needs to be given particularly to the interplay of social factors (societal religiosity) and psychological factors (e.g., personal commitment). Moreover, biology teachers, particularly those in more religious countries, need to be supported by professional development to help them overcome the conundrums that may arise from exposure to creationist ideology. We expect that the present study can illuminate the complexity of these issues and inspire additional research on how to effectively support biology teachers in scientifically sound teaching of evolution and religiosity in their country.

\section{Acknowledgements \\ This research had the financial support of Portuguese national funds through the FCT (Foundation for Science and Technology) within the framework of the CIEC (Research Center for Child Studies of the University of Minho) project under the reference UIDB/00317/2020.}

\section{Authors' contributions}

HS participated in all stages of the development of the article. AO participated in the analysis of the data and paper writing. GV and MD participated in data collection and paper writing. GSC participated in the analysis of the data and paper writing. All authors read and approved the final manuscript.

\footnotetext{
2 "It seems to me absurd to doubt that a man may be an ardent Theist and an evolutionist." (https://www.darwinproject.ac.uk/letter/DCP-LETT-12041 .xml).
} 


\section{Funding}

This research had the financial support of Portuguese national funds through the FCT (Foundation for Science and Technology) within the framework of the CIEC (Research Center for Child Studies of the University of Minho) project under the reference UIDB/00317/2020.

\section{Ethics approval and consent to participate}

The research was approved by the ethics committee, and all participants gave their consent for research collaboration.

\section{Consent for publication}

All authors have consented to the publication of the text.

\section{Competing interests}

There are no competing interests.

\section{Author details}

${ }^{1}$ University Center of Formiga-MG, Formiga, Brazil. ${ }^{2}$ State University of New York Albany, Albany, New York, USA. ${ }^{3}$ Education Training Council, National Administration of Public Education, Montevideo, Uruguay. ${ }^{4}$ Center for Studies in Philosophy and History of Sciences, National University of Matanza, San Justo, Argentina. ${ }^{5}$ Institute of Education, CIEC, University of Minho, Braga, Portugal.

Received: 23 October 2020 Accepted: 30 December 2020

Published online: 25 January 2021

\section{References}

Agnew C. Commitment, theories and typologies. https://docs.lib.purdue.edu/ psychpubs/28 2009.

Almond PC. Adam and Eve in seventeenth-century thought. Cambridge University Press; 2008.

Araujo ES, Caldeira AM, Caluzi JJ, Carvalho GS. Concepções criacionistas e evolucionistas de professores em formação e em exercício. Encontro Nacional de Pesquisa em Ciências. 2009. http://repositorium.sdum.uminh o.pt/handle/1822/9925

Avendano R, Barrera-Osorio F, Nieto-Parra S, Vever F. Understanding student performance beyond traditional factors: Evidence from PISA (No. 331). OECD Publishing, 2016. https://doi.org/10.1787/18151949

Ayala FJ. Darwin's gift to science and religion. New York: National Academies Press; 2007.

Barbour I. Religion in an age of science. San Francisco: Harper San Francisco; 1990.

Berger D, Bernard S, Wafo F, Hrair S, Balcou M, Carvalho G. Éducation à la santé et à la sexualité: Qu'enpensent les enseignants? Étude comparative dans 15 pays. Carrefours de l'Education. 2011;32:81-103.

Blancke S, Kjærgaard PC. Creationism invades Europe. Scientific American. 2016. https://www.scientificamerican.com/article/eurocreationism/

Bramble DM, Lieberman DE. Endurance running and the evolution of homo. Nature. 2004;432:345-52. https://doi.org/10.1038/nature03052.

Bravo P, Cofré H. Developing biology teachers' pedagogical content knowledge through learning study: the case of teaching human evolution. Int J Sci Educ. 2016;38(16):2500-27. https://doi.org/10.1080/09500 693.2016.1249983.

Brum E, Fonseca C, Cardoso N. E no princípio era o que mesmo? Época. 2005. http://revistaepoca.globo.com/Revista/Epoca/0,EDG68 197-6014,00-E+NO+PRINCIPIO+ERA+O+QUE+MESMO.html

Caldeira AM, Araújo ES, Carvalho GS. Creationism and evolution of Brazilian teachers and teachers-to-be. J Life Sci. 2012; 6. http://hdl.handl e.net/1822/18308

Carvalho GS, Clément P. Projecto educação em biologia, educação para a saúde e educação ambiental para uma melhor cidadania: Análise de manuais escolares e concepções de professores de 19 países (europeus, africanos e do próximo oriente). Revista Brasileira de Pesquisa em Educação em Ciências. 2007;7:1-21. http://hdl.handle.net/1822/7775

Clarke-Midura J, Pope DS, Maruca S, Abraham JK, Meir E. Iterative design of a simulation-based module for teaching evolution by natural selection. Evolution. 2018;11:4. https://doi.org/10.1186/s12052-018-0078-6
Clément P. Didactic transposition and the KVP model: conceptions as interactions between scientific knowledge, values and social practices. Proceedings of ESERA Summer School IEC, Braga (Portugal). 2006; 9-18.

Clément P. Les conceptions créationnistesd'enseignantsdans 30 pays. Varientellesenfonction de leur religion? Education etSociétés. 2014;33:113-36. https://doi.org/10.3917/es.033.0113.

Clément P. Creationism, science and religion: a survey of teachers' conceptions in 30 countries. Proc SocBehavSci. 2015;167:279-87. https://doi. org/10.1016/j.sbspro.2014.12.675.

Clément P. Omodelo KVP. Interações entre Conhecimentos, Valores e Práticas sociais. In: Oliveira Boff, ET, Pasera-de-Araùjo, MC, Carvalho, GS. Conhecimentos, valores e práticas na educação em saúde, ljui (Brasil). Ed. Unijui, Coleção nas ciências, 2016. p. 13-30.

Clément P, Quessada MP. Creationist Beliefs in Europe. Science. 2009;324(26):1644.

Clément P, Quessada MP. Les conceptions sur l'évolution biologique d'enseignants du primaire et du secondaire dans 28 pays variant selon leur pays et selon leur niveau d'étude. Actes AREF. 2013. http://hal.archi ves-ouvertes.fr/hal-01026095

Clément P, Dramisin JP, Esteves F. Creationist conceptions in 14 countries: How to teach evolution to French students coming from immigration? Berlin: ColloqueBioEd; 2009.

Collins, Francis S. The language of God: A scientist presents evidence for belief. Simon and Schuster, 2006.

Cornish-Bowden A, Cardenas ML. The threat from creationism to the rational teaching of biology. Biol Res. 2007;2007(40):113-22. https://doi. org/10.4067/S0716-97602007000200002.

Coutinho FA, Silva FARE. Ciencia e religiao: umaguerradesnecessaria. CienciaHoje. 2013;51:18-21.

Coyne JA. Why evolution is true. New York: Oxford University Press; 2010.

Cunha LA. A luta pela ética no ensino fundamental: Religiosaoulaica. Cadernos de Pesquisa. 2009;39:401-19. https://doi.org/10.1590/S0100-1574200900 0200005 .

Dawkins, Richard. The God Delusion. Random House, 2016.

Da Costa N. Non-affiliated believers and atheists in the very secular Uruguay. Religions. 2020;11:50. https://doi.org/10.3390/rel11010050.

Da Silva KAM, Mendonça F. O laicismo no Uruguai. RevistaAmeríndia-História, cultura e outros combates. 2008;3:8

Devine, Philip E. Creation and evolution. Religious studies. 1996, p. 325-337. http://www.jstor.org/stable/20019826. Accessed 30 Dec 2020.

De Asúa M. Science and integral Catholicism in interwar Argentina. Church History Religious Culture. 2019;99(3-4):485-503. https://doi. org/10.1163/18712428-09903001.

Downie JR, Barron NJ. Evolution and religion: attitudes of Scottish first year biology and medical students to the teaching of evolutionary biology. J BiolEduc. 2000;34:139-46. https://doi.org/10.1080/00219266.2000.96557 04.

El-Hani CN, Sepulveda C. The relationship between science and religion in the education of protestant biology preservice teachers in a Brazilian university. Cult Sci Edu. 2010;1:3-125. https://doi.org/10.1007/s1142 2-009-9212-7.

Enns P. The evolution of Adam: what the Bible does and doesn't say about human origins. Berlin: Baker Books; 2012.

Esquivel JC. Igreja católica e estado na Argentina e no Brasil: Notas introdutórias para uma análise comparativa. Ciencias Sociales y Religión/ Ciências Sociais e Religião. 2003;5: 191-223. https://doi.org/https://doi. org/10.22456/1982-2650.2260

Fahrenwald CR. Biology teachers' acceptance and understanding of evolution and the nature of science. 1999. Thesis (Ed.D.), University of South Dakota. Available from ProQuest Dissertations and Theses database. (UMI No. 9937374).

Falcão E. Religious beliefs: their dynamics in two groups of life scientists. Int J SciEduc. 2008;30(9):1249-64. https://doi.org/10.1080/095006907017658 63.

Galli LG, Meinardi E. Obstáculos para el aprendizajedelmodelo de evoluciónporselección natural, enestudiantes de escuelasecundaria de Argentina. CiênciaEducação (Bauru). 2015;21:101-22. https://doi.org/10.1590/1516731320150010007.

Gatti BA. Formação de professores: Condições e problemasatuais. Revistainternacional de formação de professors. 2016;1(2):161-71. https://doi. org/10.1590/1516-731320150010007. 
Glick TF. The reception of Darwinism in Uruguay. The Reception of Darwinism in the Iberian World. Berlin: Springer; 2001. p. 29-52.

Harmon K. Evolution abroad: Creationism evolves in science classrooms around the Globe. Scientific American. 2011. https://www.scientificameri can.com/article/evolution-education-abroad/.

Holt EA, Ogden TH, Durham S. The positive effect of role models in evolution instruction. Educ Outreach. 2018. https://doi.org/10.1186/s1205 2-018-0086-6.

Jalil AM. El debate creacionismo-evolución en profesores de Biología y al interior de las clases de una escuela confesional. Revista de Educación en Biología. 2009;12(2):61-3.

Khzami SE, Berger D, El Hage F, De La Forest V, Bernard S, Abrougui M, Joly J, Jourdan D, Carvalho GS. Impact of teachers' conceptions on sex education in four Mediterranean countries. Description etdéterminants des conceptions des enseignants de 4 pays méditerranéens sur l'éducation à la sexualité. Santé publique. 2008;20:527-45.

Klinghoffer D. Intelligent design shines in Brazil: More from discovery instituteMackenzie launch. Evolution News and Science Today. 2017. https:// evolutionnews.org/2017/05/intelligent-design-shines-in-brazil-morefrom-discovery-mackenzie-launch/

Leakey R. A origem da espéciehumana. Brasil: Rocco; 1995

Lefevre F, Lefevre AMC. O sujeitocoletivo que fala. Interface ComunicaçãoSaúdeEducação. 2006;10:517-24. https://doi.org/10.1590/S1414-3283200600 0200017.

Levine A, Novoa A. ¡ Darwinistas! Brill: The construction of evolutionary thought in nineteenth century Argentina; 2012.

Livingstone DN. Adam's ancestors: Race, religion, and the politics of human origins. EUA: Johns Hopkins University Press; 2008.

Lovejoy CO. The origin of man. Science. 1981;211:341-50. https://doi. org/10.1126/science.211.4480.341.

Lucero MM, Petrosino AJ, Delgado C. Exploring the relationship between secondary science teachers'subject matter knowledge and knowledge of student conceptions while teaching evolution by natural selection. J Res Sci Teach. 2017;54(2):219-46. https://doi.org/10.1002/tea.21344.

Luskin C. Human origins and intelligent design. Prog Complex Design. 2005:4:12.

Machado M, Das DC. Religion and moral conservatism in Brazilian politics. Политикологијарелигије. 2018;12(1):55-74.

MacDowell JA. Evolução VERSUS criação: falso dilEma. Veritas (Porto Alegre). 2011;56(2). https://doi.org/10.15448/1984-6746.2011.2.10842

Marin C, Elía G. Effect of academic degree and discipline on religious beliefs and evolution acceptance: Survey at a chilean university. Zygon. 2016;51:277-92. https://doi.org/10.1111/zygo.12258.

Mcgrath A, Mcgrath JC. The Dawkins delusion Atheist fundamentalism and the denial of the divine. New York: InterVarsity Press; 2011.

Miller JD, Scott EC, Okamotto S. Public acceptance of evolution. Science. 2006;313:765-6.

Morello SJ, Romero G, Rabbia C, Costa N. An enchanted modernity: making sense of Latin America's religious landscape. Crit Res Relig. 2017;5(3):30826. https://doi.org/10.1177/2050303217732131.

Munoz F, Bogner F, Clément P, Carvalho GS. Teachers' conceptions of nature and environment in 16 countries. J Environ Psychol. 2009;29:407-13. https://doi.org/10.1016/j.jenvp.2009.05.007.

Nehm RH, Reilly L. Biology majors'knowledge and misconceptions of natural selection. Bioscience. 2007;57:263-72. https://doi.org/10.1641/B570311.

Nelson CE, Lawrence CS, Jean B, Lawrence F. The nature of science as a foundation for fostering a better understanding of evolution. Evo Edu Outreach. 2019. https://doi.org/10.1186/s12052-019-0100-7.

Novaes R. Osjovenssemreligião: Ventossecularizantes, espírito de época e novossincretismos. Estudosavançados. 2004;18:321-30. https://doi. org/10.1590/S0103-40142004000300020.

Oliveira AW, Cook K, editors. Evolution Education and the Rise of the Creationist Movement in Brazil. Lanham, MD: Lexington Books; 2019.

Oliveira GS, Mota HS, Gouw AMS, Bizzo N. Comparative studies of students' beliefs and understandings in Brazil, Italy, and Galapagos Islands. In: Oliveira AW, Cook K, editors. Evolution education and the rise of the creationist movement in Brazil. Lanham, MD: Lexington Books; 2019. p. 191-208.

Oro AP. Religião, coesão social e sistema político na América Latina. iFHC/ CIEPLAN. São Paulo, Brasil, e Santiago de Chile. 2008.
Pennock RT. Creationism and intelligent design. Ann Rev Genom Hum Genet. 2003;4(1):143-63.

Pew Research Center. The age gap in religion around the world. 2018. https:// www.pewforum.org/2018/06/13/the-age-gap-in-religion-around-theworld/.

Pobiner B, et al. Using human case studies to teach evolution in high school AP biology classrooms. Evol Educ Outreach 2018;11(1):3. https://doi. org/10.1186/s12052-018-0077-7.

Quessada MP, Clément P. The origins of humankind: A survey of school textbooks and teachers' conceptions in 14 countries. AuthenBiol Educ. 2011;11:295-307.

Relethford JH. 50 great myths of human evolution: understanding misconceptions about our origins. New York: Wiley; 2017.

Salzano FM. Mito, razão e ciência. CiênciaHoje. 2005;36:28-32.

Sanz VC. La evolución del creacionismo: del mito cosmogónico a la pseudociencia biológica. História e Filosofia da Biologia. 2013;8(2):361-79. http:// hdl.handle.net/10550/34523.

Scharmann LC. Evolution and nature of science instruction. Education and Outreach. 2018. https://doi.org/10.1186/s12052-018-0088-4.

Scott EC. The creation/evolution continuum. Reports of the National Center for. SciEduc. 1999;19(4):16-7.

Sepulveda C. Movimentocriacionista: Um risco à formaçãocientífica e cultural dos alunos da redepública carioca. Boletim da SBEnBio. 2004;1:4-9.

Silva HM. Professores de biologia e ensino de evolução: Uma perspectiva comparativa em países com contraste de relação entre Estado e Igreja na América Latina. Doctoral thesis, Universidade Federal de Minas Gerais. 2015.

Silva HM. Intelligent design endangers education. Science. 2017;357(6354):880-880.

Silva HM. Ark of Absurdities. Skeptic. 2020;2:26-30.

Silva HM, Mortimer EF. Rescuing Darwin Brazil. Latin American Perspectives on Science and Religion. Pickering \& Chatto, 2014; 1. ISBN: 9781781444573

Silva HM; Mortimer EF. Brazilian high school biology teachers' perception of evolution and its teaching. Evolution education and the rise of the creationist movement in Brazil, p. 69, Lexington Books, 2019. ISBN-13: 978-1793601483

Silva HM, Mortimer EF. Teachers' conceptions about the origin of humans in the context of three Latin American Countries with Different Forms and Degrees of Secularism. SciEduc. 2020. https://doi.org/10.1007/s1119 1-020-00124-8.

Silva HM, Araújo ESNN, Silva, PR. Perception of Brazilian citizens about Darwinism and the (non) influence of God in the evolutionary process. Proceedings of INTCESS 14. In: International conference on education and social science proceedings 2014; 1390-99.

Silva HM, Mortimer EF, Gibram DE, dos Santo AH, Carvalho GS. The perspective of science and religion in high school biology teachers in Argentina, Brazil and Uruguay: a comparative study. Proc SocBehavSci. 2015;197:780-7. https://doi.org/10.1016/j.sbspro.2015.07.180.

Silva HM, Clément P, Leão IM, Garros TV, Carvalho GS. Biology Teachers'conceptions about the Origin of Life in Brazil, Argentina, and Uruguay: a Comparative Study. Zygon. 2017;52(4):943-61. https://doi. org/10.1111/zygo.12371.

Silva HM, Mortimer EF, Diaz MA, Tomasco IH, Gibram DE, Carvalho GS. The human species origin: views of biology teachers from three Latin American countries. TheolSci. 2019;17:257-72. https://doi.org/10.1080/14746 700.2019 .1596343$.

Somma NM, Bargsted MA, Valenzuela E. Mapping religious change in Latin America. Latin Am PolitSoc. 2017;59(1):119-42. https://doi.org/10.1111/ laps.12013.

Souza S. A goleada de Darwin: sobre o debate criacionismo/darwinismo. Rio de Janeiro: Record; 2009.

Souza R, Matsuo T, Zaia D. Evolucionismo x criacionismo. Revista. CiênciaHoje. 2009;2009(43):36-45.

Stringer CB, Andrews P. Genetic and fossil evidence for the origin of modern humans. Science. 1998;239:1263-8. https://doi.org/10.1126/scien ce.3125610.

Tibayrenc M, Ayala F. What makes us humans: human evolution. Biological and Cultural Domains: Nova Science Publishers; 2020

Villani A, De Freitas D. Formaaçâo de professores de ciências: Um desafio sem limites. I Encuentro Iberoamericano sobre Investigación Básica en Educación en Ciencias. 2002;12:123-42. 
Villar A, Zoido P. Challenges to quality and equity in educational performance for Latin America, a PISA 2012 perspective. RELIEVE. 2016;22(1):M9. https ://doi.org/10.7203/relieve.22.1.8273.

Wells J. Intelligent design is flourishing in Brazil. Evolution News and Science Today. 2017. https://evolutionnews.org/2017/12/intelligent-design-isflourishing-in-brazil/

Wiarda HJ. Politics and social change in Latin America: still a distinct tradition? Routledge, 2019.

Wolff E. Reformasnaigreja: chegou a vez do catolicismo? Uma aproximação dos 50 anos do Vaticano II e os 500 anos da reformaluterana, no contexto do pontificado do papa Francisco. Horizonte. 2014;12:534. https://doi. org/10.5752/P.2175-5841.2014v12n34p534.

Wood B. Origin and evolution of the genus homo. Nature. 1992;355:783-90. https://doi.org/10.1038/355783a0.

\section{Publisher's Note}

Springer Nature remains neutral with regard to jurisdictional claims in published maps and institutional affiliations.
Ready to submit your research? Choose BMC and benefit from:

- fast, convenient online submission

- thorough peer review by experienced researchers in your field

- rapid publication on acceptance

- support for research data, including large and complex data types

- gold Open Access which fosters wider collaboration and increased citations

- maximum visibility for your research: over 100M website views per year

At BMC, research is always in progress.

Learn more biomedcentral.com/submissions 